\title{
Lichen diversity in selected Coffee plantation areas of Mudigere Taluk, Karnataka; Central Western Ghats, India
}

\author{
Sudhama V. $\mathbf{N}^{1}$, Sandhya $\mathbf{R}^{2}$ \\ ${ }^{1,2}$ Department of P.G. Studies in Botany, I.D.S.G. Government College, Chikkamagaluru, Karnataka, India
}

\begin{abstract}
Lichens are one of the excellent examples of symbiotic association, are group of non-vascular cryptogams, occur in all possible environmental habitats of the world, but are diverse in tropical region and luxuriant in temperatealpine areas. Study was conducted in selected Coffee plantation areas of Mudigere taluk located in Chikkamagaluru district of Central Western Ghats. In present work about 30 species of lichens belonging to 17 genera and 13 families were enumerated from six different sites by lying quadrate. Most of the species collected were corticolous, grading their growth form $56.6 \%$ with crustose, $40 \%$ with foliose and $3.3 \%$ with fruticose thallus. Identification of these lichens done at genus level based on the colour test and relevant keys. Highest representative of six species from Parmeliaceae family, Physciaceae (5 species), Arthoniaceae (4), Graphidaceae (4), Ramalinaceae (3), Pertusariaceae (2), Caliciaceae (3) exhibited the maximum diversity in the area. The families like Collemataceae, Crysotricaceae, Stereocaulaceae, Pyrenulaceae and Lecanoraceae represented single species each. A majority of lichen species were found to favour woody habitat. The species diversity on bark demonstrated with maximum number of species because bark provides a very fertile substrate for rich growth of the lichens, whereas the soil harbours poor diversity probably due to spraying of chemicals in coffee plantation like herbicide, pesticide and fungicide.
\end{abstract}

Keywords: Diversity, Lichens, Coffee plantation, Mudigere taluk, Central Western Ghats

\section{INTRODUCTION}

Lichens are found in a wide range of habitats all over the world and dominate terrestrial ecosystems. As many as 20,000 species of lichens have been reported worldwide. In Indian subcontinent is reportedly a reservoir of 2,450 species of lichens of which India alone possesses more than 2,300 species [1]. These organisms lack protective tissues [2], due to the peculiar structure and physiology, lichens are tolerant to extreme abiotic condition and they are able to grow in the diverse geographical regions from temperate to tropical in the earth [3].

Lichens are the vital components of ecosystem [4]. Lichens can be efficiently used for monitoring the pollution levels. Thus, lichens are considered as Bio indicators of environmental pollution [5]. Lichens have adapted to all possible environmental habitats in the world in Indian context, these are more prominent and diverse in mountainous range. Eastern Himalayan and Western Ghats are two main centres of diversity in India. The Western Ghats region is also very rich in lichen flora like Angiosperms [6], lichenologically this region is richest zones in the country with abundance of many interesting taxa. However, Western Ghats remained under explored and less studied compared to vascular plants [7].

The pattern of diversity and distribution of organisms is a key aspect in conservation and management; ecologists are often concerned with patterns of species diversity [8], moreover they are disappearing from many regions at an alarming rate [9]. Habitat destruction and fragmentation are main threats to lichens [10]. Due to destruction of old growth forest all over the world, lichens are currently declining as they are very sensitive to climate change affecting survival and distribution $[11,12]$

Humans have also been exploiting lichens and their substances for various purposes since long time. The lichens have found their stand as important part of traditional medicine, dyeing agents, food, Bio indicators, etc. The lichens have been the house hold items of Indians since ancient times [13]. Lichens produce characteristic secondary metabolites exert a wide variety of biological actions including antibiotic, anti-bacterial, antiviral, anti-inflammatory, analgesic, anti-proliferative and cytotoxic effects. They also utilized commercially for enzymes, acids and pigments [14]. However, the over exploitation and excessive collection is a major threat to the existing lichen flora. For the conservation of these unique creatures and to understand their susceptibility and decline, we need to conduct extensive research on lichens.

In Karnataka, Western Ghats region, which is composed of tropical and subtropical moist forests harbour many lichens species [14]. The present investigation was undertaken for a detailed enumeration of lichen communities, their growth 


\title{
International Advanced Research Journal in Science, Engineering and Technology
}

\author{
Vol. 8, Issue 12, December 2021
}

\section{DOI: 10.17148/IARJSET.2021.81203}

form, micro habitats and host plant interaction in different regions of selected Coffee plantation areas of Mudigere taluk of Chikkamagaluru-District, Karnataka, Central Western Ghats, India.

\section{MATERIALS AND METHODS}

2.1 Study area: Field research was conducted in Mudigere taluk's coffee plantation areas. Because of its coffee cultivation, Mudigere taluk holds a distinct place in the district. Because of the altitude ranges of 915 metres above sea level, coffee is abundantly grown. The geographical region lies in latitude $13^{\circ} 08^{\prime} 02^{\prime \prime}$. The annual rainfall $3000 \mathrm{~mm}$ to $3500 \mathrm{~mm}$, mean minimum and maximum temperate is $17^{\circ} \mathrm{C}$ to $28^{\circ} \mathrm{C}$, humidity $53^{\circ} \mathrm{C}$.

\subsection{Field study:}

Survey work was carried out between April to October 2021 to make complete record of different habitats of species and their occurrence. A total of six quadrates each measuring $10 \times 10 \mathrm{~m}$ were laid down in at different sites. In each quadrate all substrate was thoroughly searched and recorded the species. Data on various species incidence in different quadrate were collected and analysed. The diversity parameters frequency, density and abundance were calculated by using standard formulas [15].

\subsection{Collection and identification:}

The representative lichen specimen collected along with their substratum irrespectively of their growth form. Only the lichens that were loosely attached to substratum was scraped out and collected. The corticolous lichens growing on tree trunk that reachable height usually collected and canopy lichens found fallen on ground was collected. Superficial bark was removed with the help of chisel by knife in order to avoid the damage of the trees. In case of Saxicolous lichens smaller pieces of the rock substrate was collected.

The collected specimens were sun dried and the lichen herbarium packets made with thick brown handmade acid free paper. The process of identification was done up to genus level on the basis of morphology, anatomy and chemical tests. The external morphology was studied under dissection microscope. The anatomical studies of thallus and apothecia were studied by taking TS and LS of thallus and apothecium respectively. The colour of medulla, apothecium, ascus and shape and size of the asci, ascospore and conidia were measured. Chemical test of the specimens includes colour spot tests. Such as K, C, KC, I and PD test and thin layer chromatography (TLC) was done. Identification of species was carried out by Indian Lichen identification keys and field guides [13, 16, 17, 18].

\section{RESULTS}

Total 30 lichens species were recorded, which belongs to the 17 genera and 13 families were collected Micro lichens were found dominated the coffee plantation with 18 species followed by Macro-lichens with 12 species (Table-1 and 2). On the lichen substratum 27 species (90\%) of Corticolous lichens and 3 species (10\%) of ramicolous lichens are present (Graph-2). the data revealed that Crustose lichens were dominated the area with 17 crustose lichens $(56.7 \%), 12$ foliose lichens (40\%) and 1 fruticose lichens (3.3\%). (Table 1 and 2, Graph-1).

The presence of more Corticolous lichens reflecting the importance of woody component of the forest as a major lichen habitat. The lichens prefer tree bark as their substratum because some lichens are more specific to their host. The member of family Parmeliaceae with 6 species, Physciaceae with 5 species, Arthoniaceae 4 species, Graphidaceae 4 species, Ramalinaceae 3 species, Pertusariaceae 2 species, Caliciaceae 3 species and family Collemataceae, Crysotricaceae, Stereocaulaceae, Pyrenulaceae and Lecanoraceae shows least diversity. In species Graphis scripta, Leptogium ulvaceum, Pertusaria pertusa and Parmelia species showed maximum frequency with $100 \%$ and Crysothrix candelaris, Pyrenula species,Lecanora species and Ramalina species 50\% shows the least frequency.

Table. 1. Lichens with host and growth forms

\begin{tabular}{|l|l|l|l|l|}
\hline Sl. No. & Name of species & Family & Host & $\begin{array}{l}\text { Growth } \\
\text { form }\end{array}$ \\
\hline 1. & Bacidia sabulentorum & Ramalinaceae & Azardiracta indica A.Juss. & crustose \\
\hline 2. & Bacidia species & Ramalinaceae & Mangifera indica L. & Crustose \\
\hline 3. & Buellia species & Caliciaceae & Citrous maximaMerr. & Crustose \\
\hline 4. & Cryptothecia scripta G. Thor & Arthoniaceae & Terminalia ellipticaWilld. & Crustose \\
\hline 5. & Chrysothrix candelaris & Chrysotrichaceae & Syzygium cumini(L.) skeels & Crustose \\
\hline 6. & Cryptothecia strita G.Thor & Arthoniaceae & Butea monosperma(Lam).Taub & Crustose \\
\hline 7. & Cryptothecia punctulate & Arthoniaceae & Acacia arabica(Lam)Willd. & Crustose \\
\hline 8. & Cryptothecia species & Arthoniaceae & Mangifera indica L. & Crustose \\
\hline 9. & Dirinaria consimilis(stirt) & Caliciaceae & Lannea coromandelica(houtt.) Merr & Foliose \\
\hline
\end{tabular}


International Advanced Research Journal in Science, Engineering and Technology

Vol. 8, Issue 12, December 2021

DOI: $10.17148 /$ IARJSET.2021.81203

\begin{tabular}{|l|l|l|l|l|}
\hline 10. & $\begin{array}{l}\text { Dirinaria applanata (Fee) D.D } \\
\text { Awasthi }\end{array}$ & Physciaceae & Pongamia pinnata (L.) Pierre & Foliose \\
\hline 11. & Graphis scripta L. Ach. & Graphidaceae & Coffea arabica L. & Crustose \\
\hline 12. & Graphis dendrographina & Graphidaceae & Michelia champaca(L.)Baill. & Crustose \\
\hline 13. & $\begin{array}{l}\text { Heterodermia } \\
\text { cosmosa(Eschw.)Follm\& Redon }\end{array}$ & Physciaceae & Areca catechu L. & Foliose \\
\hline 14. & Heterodermia obscurata (Nyl.) Trevis & Physciaceae & Citrus sinensis (L.) Osbeck. & Foliose \\
\hline 15. & $\begin{array}{l}\text { Heterodermia diademata (Taylor) D. } \\
\text { D. Awasthi }\end{array}$ & Physciaceae & Pongamia pinnata(L.) Pierre & Foliose \\
\hline 16. & Lapraria coriensis (Hue) Sipman & Stereocaulaceaea & $\begin{array}{l}\text { Grevillia robusta A.Cunn. } \\
\text { ex R.Br }\end{array}$ & Crustose \\
\hline 17. & Lecanoea species & Lecanoraceae & Pongamia pinnata (L.) Pierre & Crustose \\
\hline 18. & Leptogium ulvaceum & Collemataceae & Casuarina eqvisetifolia & Foliose \\
\hline 19. & Parmotrema species & Parmeliaceae & Citrus sinensis (L.) Osbeck. & Foliose \\
\hline 20. & Parmelia perlatum (Huds.) M. Choisy & Parmeliaceae & Manilkara zapota(L.) P.Royen & Foliose \\
\hline
\end{tabular}

Table. 2. Lichens with host and growth forms

\begin{tabular}{|l|l|l|l|l|}
\hline Sl. No. & Name of species & Family & Host & $\begin{array}{l}\text { Growth } \\
\text { form }\end{array}$ \\
\hline 21. & Parmelia species & Parmeliaceae & Manilkara zapota(L.) P.Royen & Foliose \\
\hline 22. & $\begin{array}{l}\text { Parmotrema tinctorum (Delise ex } \\
\text { Nyl.) Hale }\end{array}$ & Parmeliaceae & Gmelina arborea Roxb & Foliose \\
\hline 23. & Parmotrema cristiferum(Taylor) Hale & Pertusariaceae & Ficus racemose L. & Foliose \\
\hline 24. & $\begin{array}{l}\text { Pertusaria pertusa var.rupestris (DC) } \\
\text { Dalla Torre \&Sarnth. }\end{array}$ & Pertusariaceae & Lannea coromandelica(houtt.) Merr. & Crustose \\
\hline 25. & Pertusaria species & Parmeliaceae & Syzygium cumini(L.) & Crustose \\
\hline 26. & Pyrenula species & Pyrenulaceae & Coffea robusta L. Linden & Crustose \\
\hline 27. & Pheographis species & Graphidaceae & Coffea arabica L. & Crustose \\
\hline 28. & $\begin{array}{l}\text { Physcia aipolia (Ehrh. Ex Humb.) } \\
\text { Furnr }\end{array}$ & Physciaceaea & Mangifera indica L. & Foliose \\
\hline 29. & Ramalina species & Ramalinaceace & Areca catechu L. & Fruticose \\
\hline 30. & Thelotrema species & Graphidaceae & Grevillia robusta A.Cunn.ex R.Br & Crustose \\
\hline
\end{tabular}

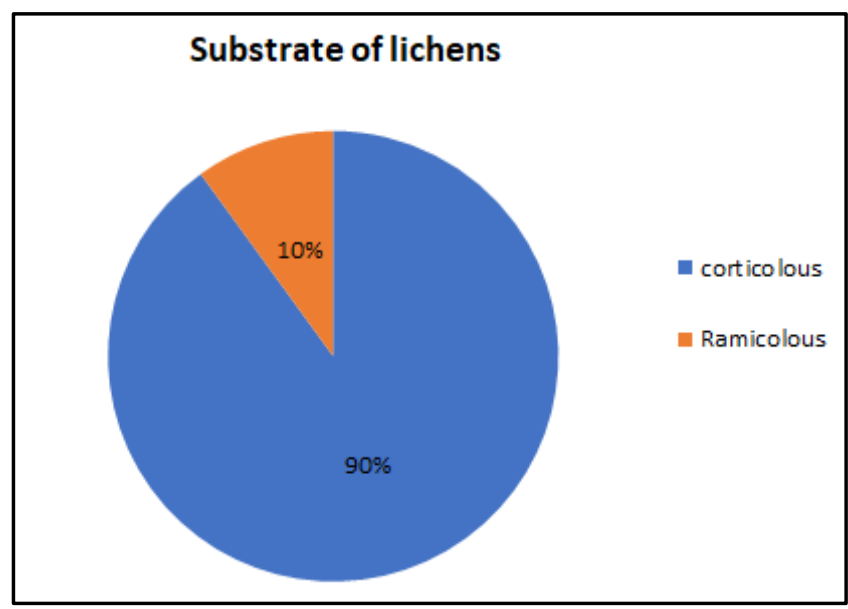

Fig. 1. Growth forms of lichens recorded at Mudigere coffee plantation 
Vol. 8, Issue 12, December 2021

DOI: $10.17148 /$ IARJSET.2021.81203

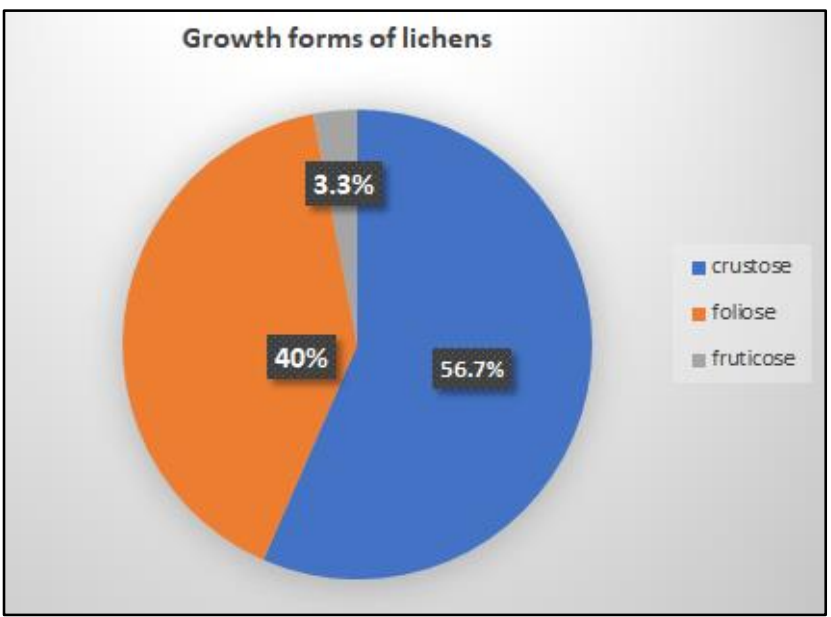

Fig.2. Substrate of lichens recorded at coffee plantation region, Mudigere.

\section{DISCUSSION}

This study found that lichen diversity in the Mudigere coffee plantation is mostly influenced by tree conditions, light exposure and pollution. Micro lichens were found dominated the coffee plantation with 18 species followed by Macro lichens with 12 species (Table-2). On the lichen substratum 27 species (90\%) of Corticolous lichens and 3 species (10\%) of ramicolous lichens are present (Graph: 2). The data revealed that Crustose lichens were dominated the area with 17 crustose lichens (56.7\%), 12 foliose lichens (40\%) and 1 fruticose lichens (3.3\%). (Table 1 and 2; Graph: 1).

The member of family Parmeliaceae with 6 species, Physciaceae with five species, Arthoniaceae and Graphidaceae four species each, Ramalinaceae and Caliciaceae three species each, Pertusariaceae (2) are dominated to the area and family Collemataceae, Crysotricaceae, Stereocaulaceae, Pyrenulaceae and Lecanoraceae shows least diversity. In species Graphis scripta, Leptogium ulvaceum, Pertusaria pertusa and Parmelia species showed maximum frequency with $100 \%$ and Crysothrix candelaris, Pyrenula species, Lecanora species and Ramalina species 50\% shows the least frequency (Table-1 and 2).

The lichen diversity in Mudigere taluk, based on size of the lichens, Microlichens were found dominated the coffee plantation. Based on types of lichens, crustose lichens were dominated to the area with $52 \%$ followed by $32 \%$ foliose lichen and fruticose lichen with only $2 \%$. According to this study Graphis scripta shows maximum frequency with $100 \%$ and Lecanora species shows least diversity [19] similarly dominance of Micro lichens was reported in montane and semi-evergreen forests [20]. A total of 48 species belonging to 25 genera and 13 families were documented in different vegetation of Koppa taluk. In that 12 species of lichens observed in semi-evergreen forest, Koppa. Among 12 species the family Physciaceae, Graphidaceae and Collemataceae are dominant to that region.

The present study also shows the similar diversity in Mudigere coffee plantation region. Correspondingly the semievergreen forests vegetation supports 111 species of macro and micro lichens in the region of Shettihalli Wildlife Sanctuary, Karnataka [14]. The Western Ghats has maximum number of crustose lichens represented by 618 taxa followed by foliose and fruticose with 269 and 62species respectively. Among different status Tamil Nadu has the highest number of lichens with 657 taxa followed by Karnataka, Kerala and Maharashtra with 336, 288 and 91 taxa respectively [13]. A report on Macro-lichen new to Karnataka, India revealed the presence of 949 species of lichens [20].

"Ecological and distribution of lichens in Bhadra wildlife sanctuary, kanivebagilu, central Western Ghats, Karnataka, India", a total of 152 species of lichens were distributes in BWS, Karnataka. They belong to 49 genera representing 27 families. In this place 143 species lichens are corticolous followed by 8 saxicolous and one terricolous lichen species are recorded [21].

In the present study, the region has two types of forest; deciduous forest and semi-evergreen forest, in that most of micro lichens are recorded from semi-evergreen forest. The lichen, Parmotrema tinctorum, Parmotrema cristiferum, Heterodermia diademata and Leptogium species were commonly distributed in deciduous and semievergreen forest. But Thelotremataceae and Graphidadaceaeous members are dominated to semi-evergreen forest. The present study also shows the similar distribution of micro lichens such as Heterodermia diademata,Parmelia, Parmotrema,Graphis, Lecanora and Leptogium species are dominated to the region of coffee plantation, Mudigere. Shettihalli Wildlife Sanctuary represents more number of corticolous lichen (90.9\%), and the present study also shows the dominance of corticolous lichens (90\%) and ramicolous lichens $(10 \%)$ which shows least diversity in the region of Mudigere coffee plantation. 


\section{CONCLUSION}

Total 30 species of lichens from 17 genera and 13 families with their host specification at 6 different sites using quadrate method. A majority of lichen species were found to favour woody habitat land and have less number of tree species. This brings the importance of woody microhabitats in promoting lichens species diversity. The deforestation rate is high and forests are being transformed into agriculture and monoculture plantations. The replacement of natural forest has both a drastic effect on species richness and lichen communities. Due to the lacking of quantitative data and frequent observation on lichens it has become difficult to assess the status of lichen diversity hence the over exploitation and cutting of forest trees should be reduced and conservation of lichen rich areas must be prioritized by declaring these areas as 'lichen sanctuaries. Also enriching the existing botanical gardens with lichens and creating lichen gardens would be effective methods to conserve them in their natural habitats, apart from conservation; they also serve as educational and recreational sites. The documentation of lichen species will provide basic information of lichen biodiversity which will helpful for future bio monitoring studies. Further research needed for periodic monitoring of the lichen communities in relation to on-going changes of local land use practices may help in promoting lichenfriendly management regime.

\section{ACKNOWLEDGMENTS}

The authors are grateful to Dr. Vinayaka K.S, Plant Biology Laboratory, Department of Botany, Sri Venkataramana Swamy College, Bantwal, Dakshina Kannada, Karnataka for constant encouragement and identification of lichens.

\section{REFERENCES}

1. Singh, K.P and Sinha, G. P. "Indian Lichens: Annotated Checklist”. Botanical Survey of India, Kolkata, 2010.

2. Nash, T.H. "Lichen Biology", second edition. Cambridge university press; Leiden UK, pp. 121-135, 2006

3. Satya, Upreti, D. K and Tandon, P. K. "Species diversity and host specificity of lichens: A case study in two forest stands of central India". International journal of ecology and environmental science, 39 (4), 239-249, 2013.

4. Gradstein, S. R. "The vanishing tropical rain as an environment for Bryophytes and lichens". Bryophytes and lichen changing environment. Clarendon Press, Oxford, pp. 234-253, 1992.

5. Trishala K. Parmar., Deepak Rawtani and Agrawal, Y. K. "Bioindicators: the natural indicator of environmental pollution". Frontiers in Life Science, 9(2), 110-118, 2016.

6. Singh, K.P. and Sinha, G.P. "Lichens. Floristic Diversity and Conservation Strategies in India". Vol. I. Botanical Survey of India, Calcutta, pp. 375-442. 1997.

7. Nayaka S. and Upreti, D. K. "Lichen flora of Sharavathi river basin. Shimoga district. Karnataka, India with six new records". Journal of Economic and Taxonomic Botany, 27, 627-648, 2002.

8. Sequiera, S. and Muktesh Kumar. "Epiphyte host relationship of macro-lichens in the tropical wet evergreen forest of silent valleys Nationalpark, Western ghats, India". Tropical ecology, 49(2), 211-224, 2008.

9. Sarah, C. Elmendorf, Gregory, H. R, Henry, Robert, D. Hollister, Robert, G. Bjo rrk, Anne D, Bjorkman et al. "Global assessment of experimental climate warming on tundra vegetation: heterogeneity over space and time". Ecology Letters, 15, 164-175, 2012.

10. Scheidegger, C. and Werth, S. "Conservation strategies for Lichens: insights from population biology". Fungal Biology Reviews, 23(3), 55-66, 2009.

11. Ellis, C. J, Coppins., B. J, Dawson., T. P, Seaward, M. R. D. "Response of British lichens to climate change scenarios, trends and uncertainties in the projected impact for contrasting biogeographic groups". Biological Conservation, 140, 217-235. 2007.

12. Ellis, C. J., Coppins, B. J., Dawson, T. P. "Predicted response of lichen epiphyte Lecanora populicola to climate change scenarios in clean-air region of Northern Britain". Biological Conservation, 135, 396-404, 2007.

13. Dalip, K. Upreti., Pradeep, K., Divakar and Sanjeeva Nayaka. “Commercial and Ethnic Use of Lichens in India”. Economic Botany, 59(3), 269-273, 2005.

14. Vinayaka K.S., Chetan H. C., Archana R. Mesta. "Diversity and distribution Pattern of Lichens in the Mid Elevation Wet Evergreen forest, Southern Western Ghats, India". International Journal of Research Studies in Bio Sciences, 4(1), 50-20, 2016.

15. Gradstein. S.R. "The vanishing tropical rain as an environment for Bryophytes and lichens" Bryophytes and lichen changing environment. Clarendon Press, Oxford, pp. 234 253, 1992.

16. Awashthi, D.D. "A key to the macro lichens of India and Nepal”. The Journal of Hattori Botanical Laboratory. 65, 207-303, 1988.

17. Awasthi, D.D. "A key to the microlichens of India, Napal and Sri Lanka". Bibliotheca Lichenologica. 40, 1- $337,1991$.

18. Singh. K. P. and Sinha. G. P. "Lichen Flora of Nagaland". Bishen Singh Mahendra Pal Singh, Dehradun, Uttarakhand, 1994.

19. Manavi Jeevala, Lichen Diversity in Mudigere Taluk, Dissertation report, Kuvempu University, Shankaraghatta, Karnataka, India, 2017.

20. Vinayaka, K.S., Praveen Kumar, S.V., Mallikarjun, N. and Prashith Kekuda, T.R. "Studies on Insecticidal activity and Nutritive composition of a macrolichen Parmotrema pseudotinctorum (des. Abb.) Hale (Parmeliaceae)". Drug Invention Today, 2(2), 102-105, 2010.

21. Vinayaka, K. S. and Krishnamurthy, Y. L. "Ecology and distribution of lichens in Bhadra Wildlife Sanctuary, Central Western Ghats, Karnataka, India". Bioremediation, Biodiversity and Bioavailability, Global science books, 5(1): 68-72, 2011. 